\title{
Modeling and Spatialization of Biomass and Carbon Stock Using Lidar Metrics in Tropical Dry Forest, Brazil: Preliminary Results
}

Robson Borges de Lima ( $\square$ rblflorestal@yahoo.com.br)

Universidade do Estado do Amapá https://orcid.org/0000-0001-5915-4045

Cinthia Pereira de Oliveira

Universidade do Estado do Amapá

Rinaldo Luiz Caraciolo Ferreira

Universidade Federal Rural de Pernambuco

José Antônio Aleixo da Silva

Universidade Federal Rural de Pernambuco

Emanuel Araújo Silva

Universidade Federal Rural de Pernambuco

Anderson Francisco da Silva

Universidade Federal Rural de Pernambuco

Josias Divino Silva de Lucena

Universidade Federal Rural de Pernambuco

Nattan Adler Tavares dos Santos

Universidade Federal Rural de Pernambuco

Iran Jorge Corrêa Lopes

Universidade Federal do Parana

Mayara Maria de Lima Pessoa

Universidade Federal Rural de Pernambuco

Cybelle Laís Souto-Maior Sales de Melo

Universidade Federal Rural de Pernambuco

\section{Research}

Keywords: Caatinga domain, Forest management, Allometry, Statistical models

Posted Date: August 11th, 2020

DOI: https://doi.org/10.21203/rs.3.rs-55277/v1 
License: (c) (i) This work is licensed under a Creative Commons Attribution 4.0 International License. Read Full License 
1 Modeling and Spatialization of Biomass and Carbon Stock Using Lidar Metrics

4 Cinthia Pereira de Oliveira $^{1}$, Rinaldo Luiz Caraciolo Ferreira ${ }^{2}$ José Antônio Aleixo da

5 Silva $^{2}$ Robson Borges de Lima $^{1}$, Emanuel Araújo Silva ${ }^{2}$, Anderson Francisco da

6 Silva $^{2}$, Josias Divino Silva de Lucena ${ }^{2}$, Nattan Adler Tavares dos Santos ${ }^{2}$, Iran Jorge

7 Corrêa Lopes ${ }^{3}$, Mayara Maria de Lima Pessoa ${ }^{2}$, Cybelle Laís Souto-Maior Sales de $8 \mathrm{Melo}^{2}$

9

* Corresponding author: Robson Borges de Lima - $\underline{\text { rbl_florestal@yahoo.com.br }}$

${ }^{1}$ Laboratório de Manejo Florestal, Universidade do Estado do Amapá, Rua Presidente

2 Laboratório de Manejo de Florestas Naturais "José Serafim Feitosa Ferraz",

Departamento de Ciência Florestal, Universidade Federal Rural de Pernambuco, Rua

Dom Manuel de Medeiros, s/n - Dois Irmãos, Recife, Pernambuco, CEP 52171-900, Brasil

3 Departamento de Ciência Florestal, Universidade Federal do Paraná, Av. Prefeito

Lothário Meissner, 632 - Jardim Botânico, Curitiba - PR, CEP 80210-170

Email address

cinthia.florestal@gmail.com;

rinaldo.ferreira@ufrpe.b;

emanuel.araujo@ufrpe.br;

engf.anderson@gmail.com; josiaslucenaeng@gmail.com; nattantavares@gmail.com; 


\section{Abstract}

Background: In recent years, with the growing environmental concern regarding climate change, there has been a search for efficient alternatives in indirect methods for studies on the quantification of biomass and forest carbon stock. In this article, we seek to obtain pioneering and preliminary results of estimates of biomass and carbon using data from conventional forest inventory and LiDAR technology in a dry tropical forest in Brazil. We used data from conventional forest inventory in two areas together with data from the LiDAR overflight, generating local biomass estimates from a developed local equation and the carbon levels obtained from local species. With data from LiDAR technology, we extracted the metrics from the point cloud and were used as an independent variable. For the construction of the biomass and carbon allometric models per hectare, we approach three types of models for data analysis: Multiple linear regression with Principal Components - PCA, Conventional multiple linear regression and Multiple linear regression with Stepwise, the generated equations were analyzed by comparisons of statistical criteria ( $\mathrm{R}^{2} \mathrm{aj}$ and RMSE). After selecting the best equation, we generate the carbon estimates by area by assessing the plot level.

Results: The best fit TAGB and TAGC model was the multiple linear regression with Stepwise, concluding, then, that LiDAR data can be used to estimate biomass and total carbon in dry tropical forest, proven by an adjustment considered in the models employed, with a significant correlation between the LiDAR metrics.

Conclusions: Our preliminary results provide important information about the spatial distribution of TAGB and TAGC in the study area, which can be used to manage the reserve for optimal carbon sequestration. 
52 Keywords: Caatinga domain, Forest management, Allometry, Statistical models

\section{Introduction}

The increase in the carbon dioxide concentration $\left(\mathrm{CO}_{2}\right)$ in the atmosphere in the last decades and its consequences on the environment have been attracting the attention of society and being addressed as a matter of global controversy (Crowther et al. 2015). The high $\mathrm{CO}_{2}$ concentration in the atmosphere is worrying, as it generates an increase in the greenhouse effect, and consequently causes global warming (Achard and House 2015; Coomes et al. 2017; Brahma et al. 2018). In this scenario, dry tropical forest areas play an important role, and the Caatinga vegetation in northeastern Brazil significantly contributes to the global carbon cycle through the aboveground biomass and carbon stock (Sampaio and Silva 2005; Althoff et al. 2018).

There is currently a rich ongoing discussion among scientists around the world about the main tools and methods for generating measures to mitigate climate change. The first guiding question to be answered is "how do we measure the impacts of global climate change and how can we slow its progress?" The second key question is "what tools and methods should be used to ensure a reliable estimate?" $\mathrm{n}$ many cases, the variables best known for generating rapid responses for dry tropical forest ecosystems are aboveground biomass and carbon.

However, the destructive sampling of trees is a limiting factor for calibrating statistical models, mainly due to the high cost employed in field work (Duncanson et al. 2017). These methods are currently based on forest inventory data using carbon factors and equations which transform the biometric parameters of the forest such as diameter at breast height $(\mathrm{DBH})$ and height $(\mathrm{Ht})$ of individuals in estimating the carbon stock contained in aboveground forest biomass (Somogyi et al. 2007). 
Remote sensing techniques combined with optical sensors have recently been

presented as a viable alternative for estimating the biomass and carbon stock in planted and natural forests (Silva et al. 2016; Silva et al. 2017a). Among the current remote sensing techniques, laser tillering, also known as LiDAR (Light Detection and Raging), has prominently emerged in the forest scenario ( $\mathrm{Li}$ et al. 2017), by which biomass and carbon stock estimates can be systematically and efficiently obtained in the field (Duncanson et al. 2017).

LiDAR is an active system, and its principle consists of emitting a laser pulse which interacts with an object on the earth's surface and subsequently returns to the sensor in a given time interval. The technology makes it possible to accurately reproduce Digital Terrain Models (DTM, models which enable describing the elevation of land free of objects), Digital Surface Models (DSM, models which enable describing the elevation of the terrain including the objects present), and Digital Height Models (DHM, models which describe the height of all objects, with the cloud points referring to the ground normalized to zero).

Although LiDAR technology is an efficient alternative and widely applied in forest inventory in countries like the United States, Finland and Sweden, there are still obstacles to its use in other countries such as Brazil. The limitations are not due to the functioning of the technology itself, but mainly because it is still an emerging technology in Brazil (Silva et al. 2017b). The elaboration of processing methodologies aimed at Brazilian needs is still recent, and in this respect the execution of this work is mainly justified by the search for a scientific technical advance which provides developing routines which can assist in LiDAR data acquisition and processing, and in turn seeking to efficiently attain above-ground biomass and carbon stock estimates in a Brazilian dry tropical forest. 
In particular, LiDAR technology has the ability to directly measure the vegetation attributes (metrics) on a vertical scale with high precision, and therefore a system can be developed to sample the biomass and carbon stock of the trees in situ in environmental gradients, providing a potential solution to outstanding problems related to forest biomass and above-ground carbon stock (Saatchi et al. 2009; Avitabile et al. 2011). Biomass and carbon estimates at local and regional levels, as well as the spatialization of these variables using maps can provide an overview of biodiversity and forest structure (Martinuzzi et al. 2013; Nelson et al. 2017; Becknell et al. 2018). This information is extremely important for the caatinga vegetation domain in Pernambuco for possible payments for environmental services and other projects aimed at reducing emissions from deforestation and forest degradation (REDD +).

Due to the great importance of caatinga forest resources, quantifying and mapping biomass and carbon stock using LiDAR metrics is a key factor to meet the legal aspects concerning sustainable management, mainly reconciling sustainable wood production and stock maintenance of carbon in the area. This task is one of the main long-term planning tools, because in addition to dimensioning the forest's stock and productivity, it generates information which will direct ecosystem maintenance through conservation and/or preservation (Mohebalian and Aguilar 2018).

In this sense, this work was developed with the intention of generating information on biomass and carbon stock using LiDAR metrics in different dry tropical forest areas in the municipality of Floresta, Pernambuco. Specifically, it is intended to: a) Estimate the total biomass and carbon stock for the parcels inventoried in two areas using a local allometric model; b) Use the aerial LiDAR system to generate attributes in plots in the different dry forest areas inventoried in Pernambuco; c) Develop an allometric model for estimating biomass and carbon stock using LiDAR metrics for the 
different dry forest areas inventoried in Pernambuco; d) Generate biomass and carbon stock maps for the different dry forest areas inventoried in Pernambuco.

Results

\section{Preliminary results}

The average minimum and maximum elevation values which correspond to the tree heights obtained by the LiDAR metrics ranged from 1.49 to 4.77 meters with an average of $3.06 \mathrm{~m}$ for the Correntão area. There is little difference in the minimum elevations per plot $(1.39 \mathrm{~m})$ for the Transposição area, but this area had the lowest average elevation $(2.88 \mathrm{~m})$ and the highest maximum elevation $(5.05 \mathrm{~m})$. The highest biomass and total carbon concentration per hectare was observed in the Correntão area

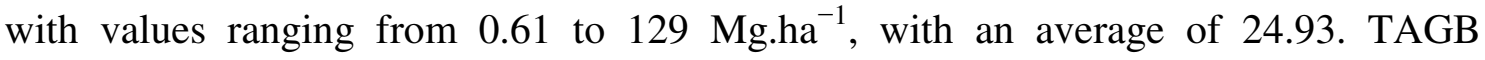
estimates for all plots in the Transposição area ranged from 1.22 to $29.37 \mathrm{Mg} . h a^{-1}$, with an average value of $9.32 \mathrm{Mg}^{\mathrm{h}} \mathrm{ha}^{-1}$.

The component loads (correlations between each variable and each principal component), the eigenvalues and the variation percentage of the principal components for the LiDAR metrics for the Transposição and Correntão areas are shown in Tables 4 and 5, respectively. The principal component analysis of the Transposição metrics produced three principal components which synthesized $85.6 \%$ of the variability in the data. The first principal component (PC1) of the metrics in this area had a high load of all variables with maximum contribution from the average increase (0.996). The principal component analysis for the metrics of the Correntão area also produced three

147 principal components which synthesized $82.8 \%$ of the variability in the data. The first 148 principal component (PC1) for the metrics in this area had maximum loads for maximum elevation and average elevation. The principal components which only represented a small amount of variance were not used in the regression analysis. 
152 Table 4. Component loads, eigenvalues and percentage of variation of the main 153 components (PC) for the LiDAR metrics in the Transposição area.

\begin{tabular}{|c|c|c|c|c|c|c|c|c|c|c|c|c|}
\hline \multirow[b]{2}{*}{$\begin{array}{l}\text { Principal } \\
\text { component }\end{array}$} & \multicolumn{12}{|c|}{ Components (eigenvectors) } \\
\hline & $\begin{array}{c}\text { Elev. } \\
\text { minimum }\end{array}$ & $\begin{array}{c}\text { Elev. } \\
\text { maximum }\end{array}$ & $\begin{array}{l}\text { Elev. } \\
\text { mean }\end{array}$ & $\begin{array}{l}\text { Elev. } \\
\text { mode }\end{array}$ & $\begin{array}{l}\text { Elev. } \\
\text { stddev }\end{array}$ & $\begin{array}{l}\text { Elev. } \\
\text { CV }\end{array}$ & $\begin{array}{c}\text { Elev. } \\
\text { skewness }\end{array}$ & $\begin{array}{c}\text { Elev. } \\
\text { kurtosis }\end{array}$ & $\begin{array}{l}\text { Elev. } \\
\text { MAD. } \\
\text { median }\end{array}$ & $\begin{array}{l}\text { Elev. } \\
\text { P01 }\end{array}$ & $\begin{array}{c}\text { Auto } \\
\text { valores }\end{array}$ & $\operatorname{Var}(\%)$ \\
\hline PC1 & 0.285 & 0.678 & 0.996 & 0.759 & 0.719 & 0.333 & -0.231 & -0.192 & 0.689 & 0.420 & 12.463 & 51.929 \\
\hline $\mathrm{PC} 2$ & -0.395 & 0.621 & 0.070 & -0.020 & 0.675 & 0.902 & 0.738 & 0.151 & 0.590 & -0.508 & 5.841 & 76.266 \\
\hline PC3 & 0.622 & 0.281 & -0.009 & -0.070 & -0.027 & 0.016 & 0.597 & 0.672 & -0.203 & 0.602 & 2.255 & 85.663 \\
\hline
\end{tabular}

154 by LiDAR data

Table 5. Component loads, eigenvalues and percentage of variation of the main components (PC) for the LiDAR metrics in the Correntão area.

\begin{tabular}{|c|c|c|c|c|c|c|c|c|c|c|c|c|}
\hline $\begin{array}{l}\text { Principal } \\
\text { component }\end{array}$ & \multicolumn{12}{|c|}{ Components (eigenvectors) } \\
\hline PC1 & 0.019 & 0.825 & 0.999 & 0.709 & 0.708 & 0.158 & -0.192 & 0.170 & 0.557 & 0.305 & 13.233 & 55.136 \\
\hline $\mathrm{PC} 2$ & -0.130 & 0.423 & 0.018 & -0.302 & 0.675 & 0.943 & 0.708 & -0.179 & 0.633 & -0.234 & 4.119 & 72.299 \\
\hline PC3 & 0.765 & -0.283 & 0.016 & -0.106 & 0.074 & 0.110 & -0.103 & -0.805 & 0.359 & 0.636 & 2.524 & 82.815 \\
\hline
\end{tabular}

The results of the step-by-step regression analysis for each area are shown in Table 6. The variables which did not significantly contribute to the TAGB prediction for each area were simultaneously eliminated during the analysis. The determination coefficient ( $\mathrm{R}^{2}$ aj) of the models for the Transposição area varied from 0.17 to 0.42 and

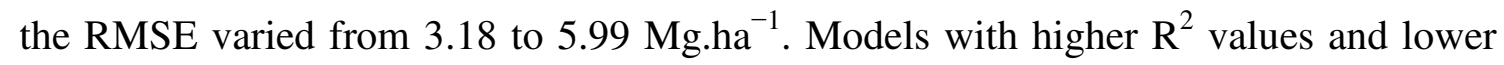
RMSE indicate better TAGB prediction. Models developed using the principal component technique of the LiDAR metrics for each area generally had an unsatisfactory performance.

Table 6. Multiple linear regression models adjusted for the biomass estimate, obtained 


\begin{tabular}{|c|c|c|c|c|}
\hline Area & & Biomass predictive models & $\mathrm{R}^{2}$ ajd & RMSE \\
\hline \multirow[t]{3}{*}{ Transposição } & $\begin{array}{l}\text { Multiple } \\
\text { regression }\end{array}$ & $\begin{array}{c}\text { TAGB }=-86.809-33.295(\text { Elev.minimum })+ \\
\text { 5.446(Elev.maximum) }+195.226(\text { Elev.mean })+3.774 \\
(\text { Elev.mode) }-92.658(\text { Elev.stddev })+206.851(\text { Elev.CV }) \\
+13.627(\text { Elev.skewness })-1.734 \text { (Elev.kurtosis })+ \\
\text { 24.360(Elev.MAD.median) }+29.676(\text { Elev.P01) - } \\
\text { 25.707(Elev.P10) -64.704(Elev.P20) }+ \\
\text { 49.118(Elev.P25) -26.958(Elev.P30) -44.133(Elev.P50) } \\
-21.226 \text { (Elev.P60) -11.419(Elev.P75) 2.295(Elev.P80) - } \\
\text { 27.855(Elev.P90) -15.740(Elev.P95) }+ \\
\text { 98.142(Canopy.relief.ratio) }+ \\
\text { 0.024(Percentage.all.returns.above.1.30) }\end{array}$ & 0.1924 & 3.18 \\
\hline & $\begin{array}{l}\text { Stepwise } \\
\text { regression }\end{array}$ & $\begin{array}{c}\text { TAGB }=-21.08-35.756(\text { Elev.minimum) }+119.784 \\
\text { (Elev.mean) + 4.582(Elev.mode) }-63.752 \\
\text { (Elev.stddev) + 101.103(Elev.CV) }+27.823(\text { Elev.P01) } \\
\text {-17.626(Elev.P10) }-29.152(\text { Elev.P20) - } \\
\text { 44.745(Elev.P50) }-18.032 \text { (Elev.P90) }\end{array}$ & 0.4239 & 3.51 \\
\hline & $\begin{array}{c}\mathrm{PCA} \\
\text { regression }\end{array}$ & $\mathrm{TAGB}=9.145+0.607($ Dim. 1$)+1($ Dim.3 $)$ & 0.1723 & 5.99 \\
\hline \multirow[t]{3}{*}{ Correntão } & $\begin{array}{l}\text { Multiple } \\
\text { regression }\end{array}$ & 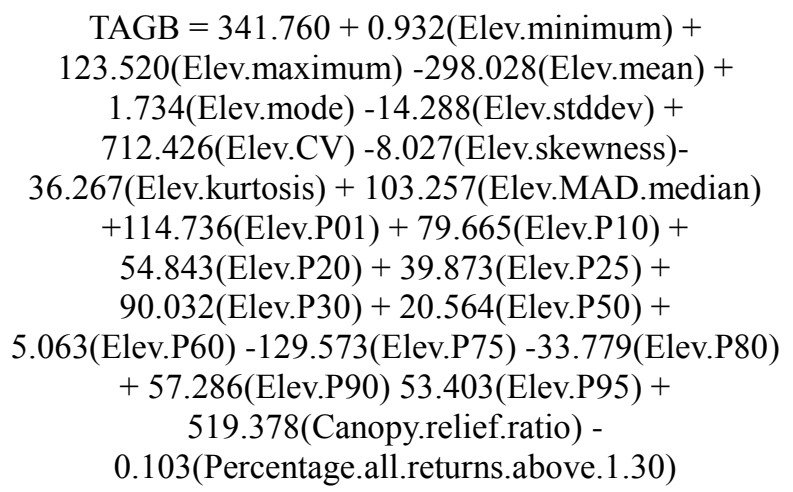 & 0.4239 & 13.61 \\
\hline & $\begin{array}{l}\text { Stepwise } \\
\text { regression }\end{array}$ & 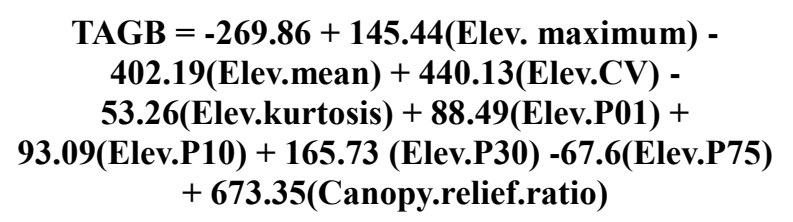 & 0.533 & 14.76 \\
\hline & $\begin{array}{c}\mathrm{PCA} \\
\text { regression }\end{array}$ & $\mathrm{TAGB}=30.270-6.465(\mathrm{Dim} .3)$ & 0.09621 & 28.45 \\
\hline
\end{tabular}


regression modeling, although the prediction error of the multiple model was slightly lower. Based on the adjustment statistics, the Stepwise regression model was considered the most suitable for predicting TAGB for both areas and this can be illustrated in the figure 5 .
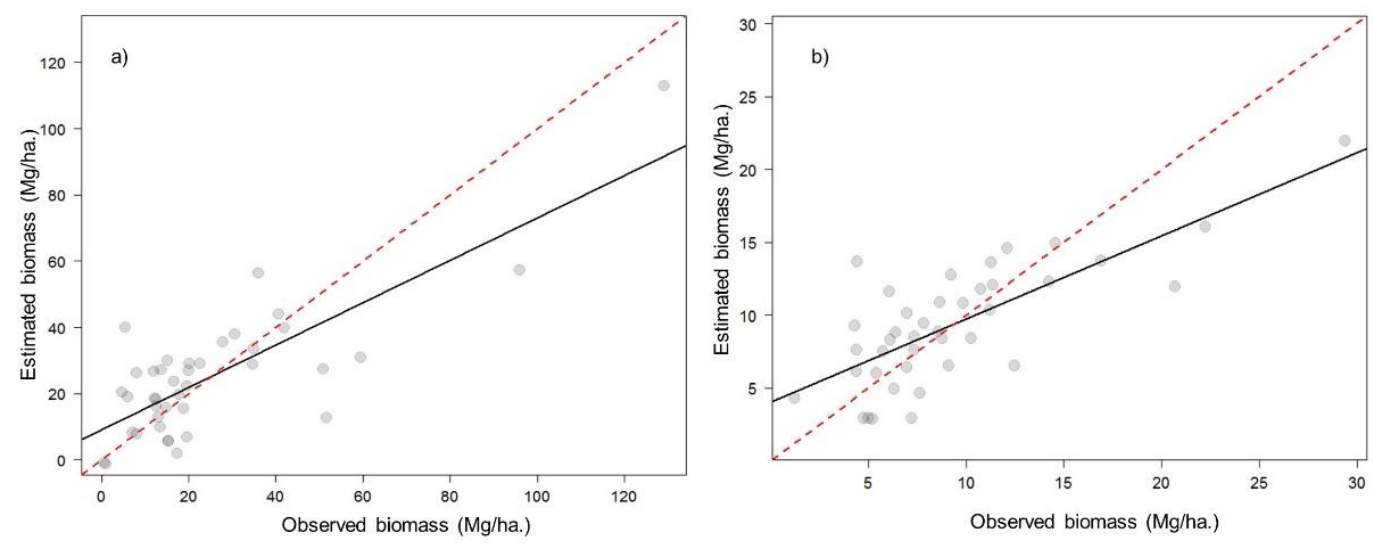

Fig. 5 Predictions of the best allometric equations for the Correntão area (a) and Transposição (b) using the LiDAR metrics selected step by step in relation to the observed values. The solid black line indicates the fit of the equation and the red dotted line indicates the ideal fit in a 1: 1 ratio.

The most significant predictor variables for the model for the Transposição area, and therefore the most suitable for predicting local TAGB, were Elev.minimum, Elev.maximum, Elev.mean and Elev.P01; the last two were found in all tested models. The final model for the Correntão area predicts that the total biomass stock may be more significant from the Elev metrics. Maximum, Elev.mean, Elev.CV, Elev.kurtosis, Elev.P01, Elev.P10, Elev.P30, Elev.P75 and Canopy.relief.ratio.

The Stepwise regression model was applied to map the density of TAGB in the study areas (Fig. 6). The TAGB map was converted to carbon stock/Mg.ha' ${ }^{-1}$ (TAGC) maps to predict the total stock in the areas using the average carbon fraction (0.48), as estimated in this study. The estimated average density of TAGB and TAGC for the 


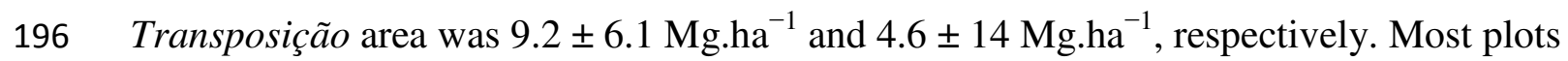

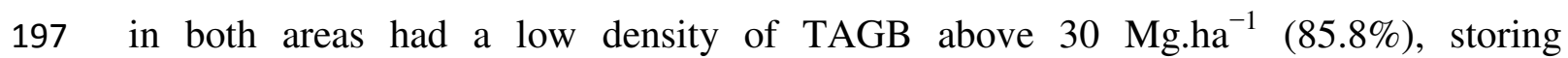
198 approximately $44.1 \%$ of the TAGC stock. About $1.2 \%$ of the forest stand in the area in

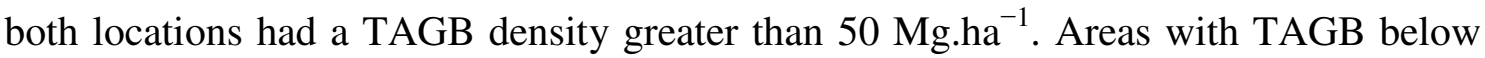
$100 \mathrm{Mg} \cdot \mathrm{ha}^{-1}$ cover about $99 \%$ of the forest stand. Low density areas of TAGB and 201 TAGC, as shown in the maps, are potential areas for assisted regeneration and enrichment planting to increase the carbon sequestration capacity of the forest stand.
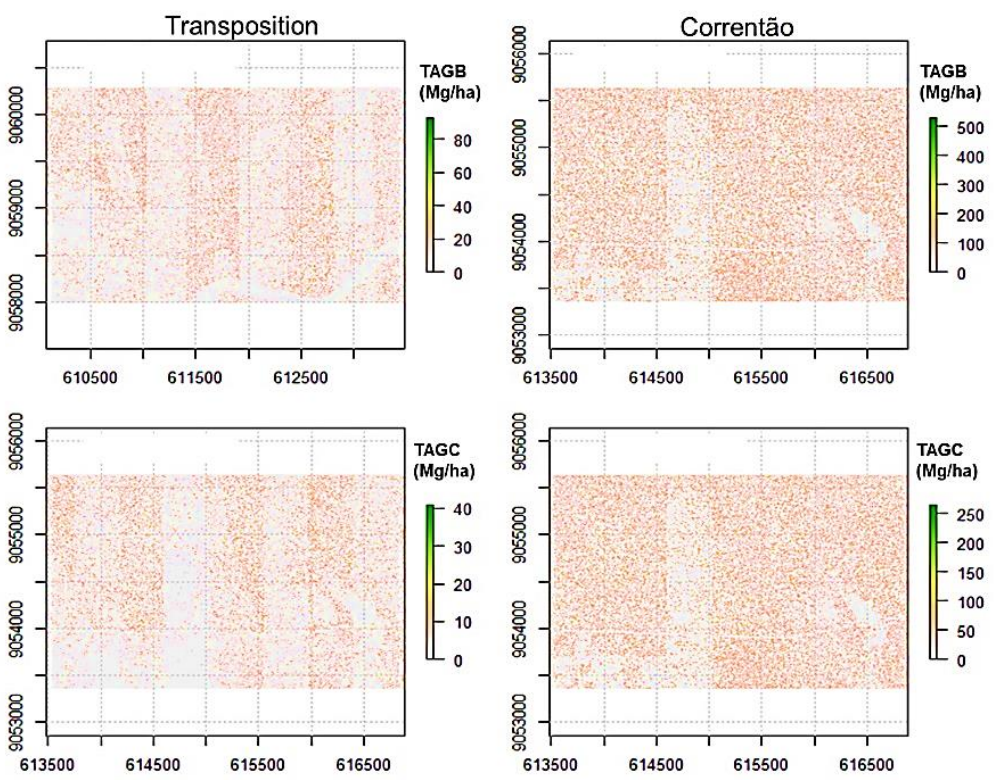

Fig. 6 Spatialization of biomass and carbon based on Stepwise regression models defined according to the LiDAR metrics for the Transposição and Correntão areas.

When comparing the areas, it is noted that the most preserved area

(Fig. 6). This can be explained in the inventories carried out in the degraded area, which 210 showed individuals with greater dominance than in the preserved area, strongly influencing the predicted biomass and carbon values. 
214 better interpretation of the results obtained in this work, namely: the density of pulses emitted by LiDAR, the characteristics of the vegetation trunks/stems studied and the effect of water stress on leaves.

217

\section{Discussion}

219 The preliminary results of this study indicate that the LiDAR metrics provided reliable estimates of TAGB and TAGC for the two study areas. The results show a good statistical relationship between field biomass data and height (elevation) metrics, suggesting that it is an important predictor of local biomass, especially when selected using the Stepwise method. However, the relationship was weaker in both areas when all metrics were incorporated into the traditional modeling process or when using metrics (minimum, average and maximum) explained more than $40 \%$ of the variance. This suggests that the incorporation of height data may be necessary to improve the prediction of TAGB and TAGC.

The $\mathrm{R}^{2}$ and RMSE values of the best-fit models vary in similar studies which used LiDAR data and metrics to estimate and map the aboveground biomass of trees in dry forests. (Anderson et al. 2018) reported $\mathrm{R}^{2}$ values ranging from 0.36 to 0.71 and RMSE values from 99 to $175 \mathrm{Mg} \cdot \mathrm{ha}^{-1}$ in Idaho (USA) based on machine learning data. In a dry tropical forest in Mexico, (Hernández-Stefanoni et al. 2015) reported $\mathrm{R}^{2}$ from 0.77 and RMSE from 21.6 to $25.7 \mathrm{Mg} \cdot \mathrm{ha}^{-1}$ based on linear regression and LiDAR data. Also in Idaho (USA), (Li et al. 2017) reported $\mathrm{R}^{2}$ of 0.87 and RMSE of $3.59 \mathrm{~kg}$ based on linear regression and data on percentage plant cover derived from ALS. (Chen et al. 2015) reported $\mathrm{R}^{2}$ ranging from 0.38 to 0.64 in the Amazon based on mixed-effect 
models and LiDAR data from agroforestry systems. The biomass estimates by the tested methodologies showed satisfactory and promising results in all of these cases.

The best-fit TAGB model consisted of $10 \mathrm{LiDAR}$ predictor variables for the Transposição area and 9 LiDAR predictor variables for the Correntão area. These variables indicate that the vertical profile of vegetation at different elevations (minimum, medium and maximum heights) are potential predictors for TAGB. TAGB estimation and mapping for the studied forest was based on the best-fit model.

The spatial distribution pattern of TAGB is related to the structure and composition of the forest landscape, where low TAGB areas correspond to low forest cover areas, while high biomass areas correspond to densely forested areas. The overall

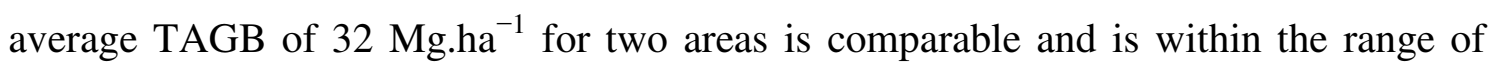
values reported for mature dry tropical forests in previous studies, indicating that the modeling approach used in this study provides reasonable predictions of TAGB (Martinuzzi et al. 2013; Kachamba et al. 2017; Naveenkumar et al. 2017).

Uncertainties in the TAGB estimates in this study could result from errors associated with field measurements, however plot TAGB estimates are based on a location-specific allometric equation with the breadth of data covering a wide sample in the model development, showing an accurate TAGB estimate. Any errors associated with the TAGB estimate at the plot level using a pantropical equation would propagate to the TAGB regression model, and therefore to the TAGB estimates (Chave et al. 2005; Chave et al. 2014). However, another possible source of error in biomass predictions may be the density of points adopted, as $0.5\left(\mathrm{pulses} / \mathrm{m}^{2}\right)$ were adopted in the data used, while carbon quantification works generally work with 4 to 25 points (Silva et al. 2014; Figueiredo et al. 2016; Nelson et al. 2017; Coomes et al. 2017). Through tests with point density, Silva et al. (2017) found that its reduction can result in a 
263 decrease in $\mathrm{R}^{2}$ and an increase in RMSE, in addition to increasing the variance of AGB 264 estimates. (Leitold et al. 2015) obtained bias in height estimates which translated into errors of $80-125 \mathrm{Mg} \cdot \mathrm{ha}^{-1}$, when the operator worked with the pulse density below $4 \mathrm{~m}^{2}$. little affect results; however, once the pulse drops to $1 / \mathrm{m}^{2}$, it makes metrics related to coverage (canopy coverage, tree density and shrub coverage) more sensitive to changes in this density (Magnusson et al. 2007). Thus, the increase in RMSE can be explained by the less accurate classification of soil returns (Silva et al. 2017a; Silva et al. 2017b). However, it is worth noting that the low density of points can also be related to good results, depending on the variable to be studied, such as canopy metrics (Thomas et al. 2006) or volume (Takahashi et al. 2010). In addition, the TAGC for the study area was estimated based on the TAGB and the average carbon fraction of the trees; any errors in the TAGB estimate would extend to the TAGC estimates. However, the results of this study indicate that the TAGB model provided reliable TAGB estimates for the study area.

\section{Conclusions}

According to the results found in this work, we concluded that LiDAR data can be used for estimating biomass and total carbon in dry tropical forest, as confirmed by an adjustment considered in the models used, with good correlation between the LiDAR metrics and the biomass data observed in the field. More specifically, we have the following conclusions and recommendations for future work:

i) Using Stepwise to reduce the metrics proved to be more effective for better adjustment of the models; 
289 ii) The LiDAR metrics which were most present in the models were: Elev.minimum,

iii) The most preserved area had a lower carbon stock than the most degraded area, this occurrence can be explained in the inventories carried out in the area that showed a higher $\mathrm{DAB}$ number in the degraded area than in the preserved area, strongly influencing the estimated carbon values in the areas;

296

iv) The pulse density, even though it is not a variable within the models, indirectly influenced the accuracy of the models, therefore, it is recommended that data be tested with a higher pulse density in future works.

300

301 and precipitation.

305

306

v) The model is limited to the TAGB estimate in the study area and may not be suitable for application in other forests. This is due to differences in forest structure, species composition, vegetation vigor and impacts of atmospheric conditions and soil moisture

vi) New studies are recommended to assess the transferability of the model to other protected forests with forest structure and similar species composition. Other studies that will test the ability of non-parametric algorithms (such as random forest) to develop TAGB estimation models for the study area, in comparison with linear regression analysis, are also recommended. 
vii) Our preliminary results provided important information on the spatial distribution of

313 TAGB and TAGC in the study area, which can be used to manage the reserve for 314 optimal carbon sequestration.

Materials and methods

317 Study area

318 The work was carried out in two semiarid areas of Itapemirim farm. Its extension is approximately $60 \mathrm{~km}^{2}$ (Fig. $1 \mathrm{D}$ ), located in the Municipality of Floresta in the São Francisco mesoregion in Pernambuco, northeast Brazilian $\left(8^{\circ} 30^{\prime} 37^{\prime \prime} \mathrm{S}\right.$ and $37^{\circ} 59^{\prime} 07^{\prime \prime}$ $\mathrm{W})$.
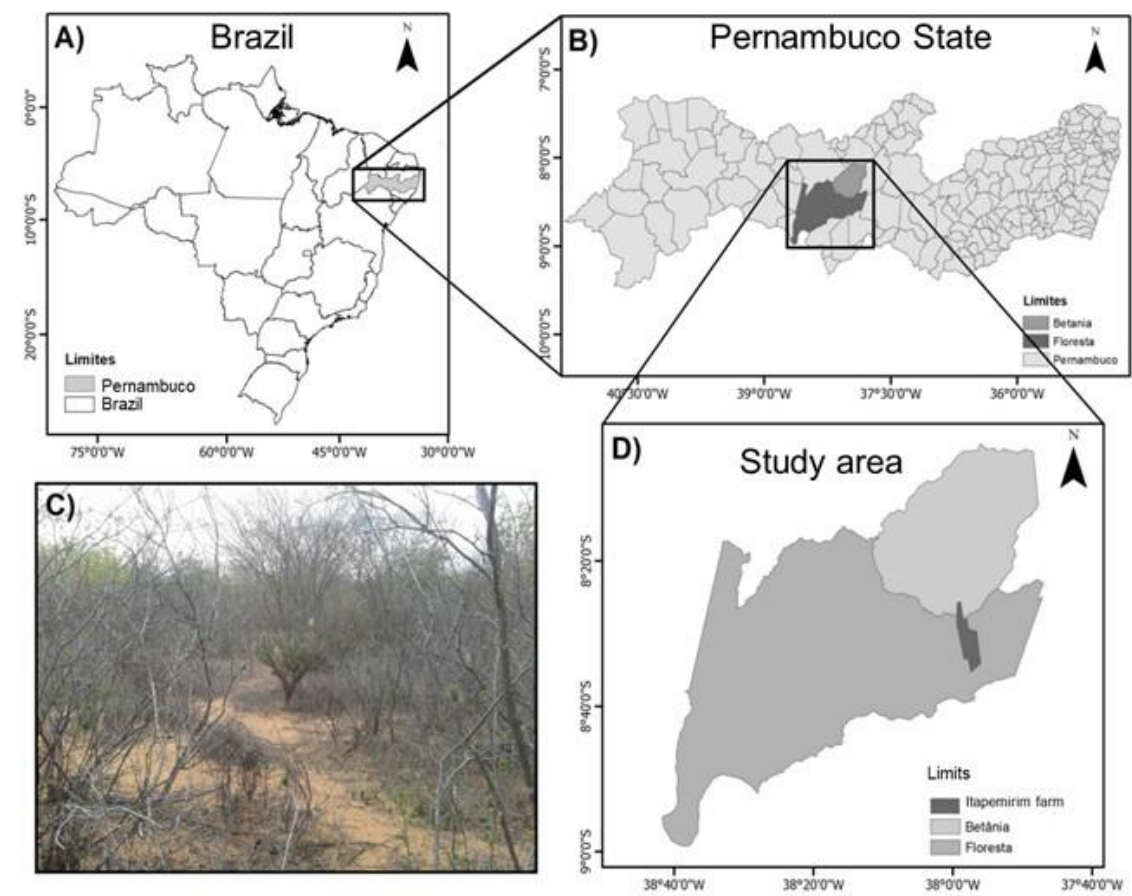

Fig. 1 Coverage of the study area: A, B and D, and profile photo in Floresta C, in the hinterland of Pernambuco, Brazil.

The two study areas differ from each other in terms of preservation conditions. 
330 years of lesser anthropic disorders). The second area further south, also with 40

331 permanent plots of $400 \mathrm{~m}^{2}(20 \times 20 \mathrm{~m})$ called "Correntão", underwent logging using the

332 Correntão technique in 1987 for planting eucalyptus, but was abandoned and has been 333 undergoing regeneration for 29 years (Fig. 2).

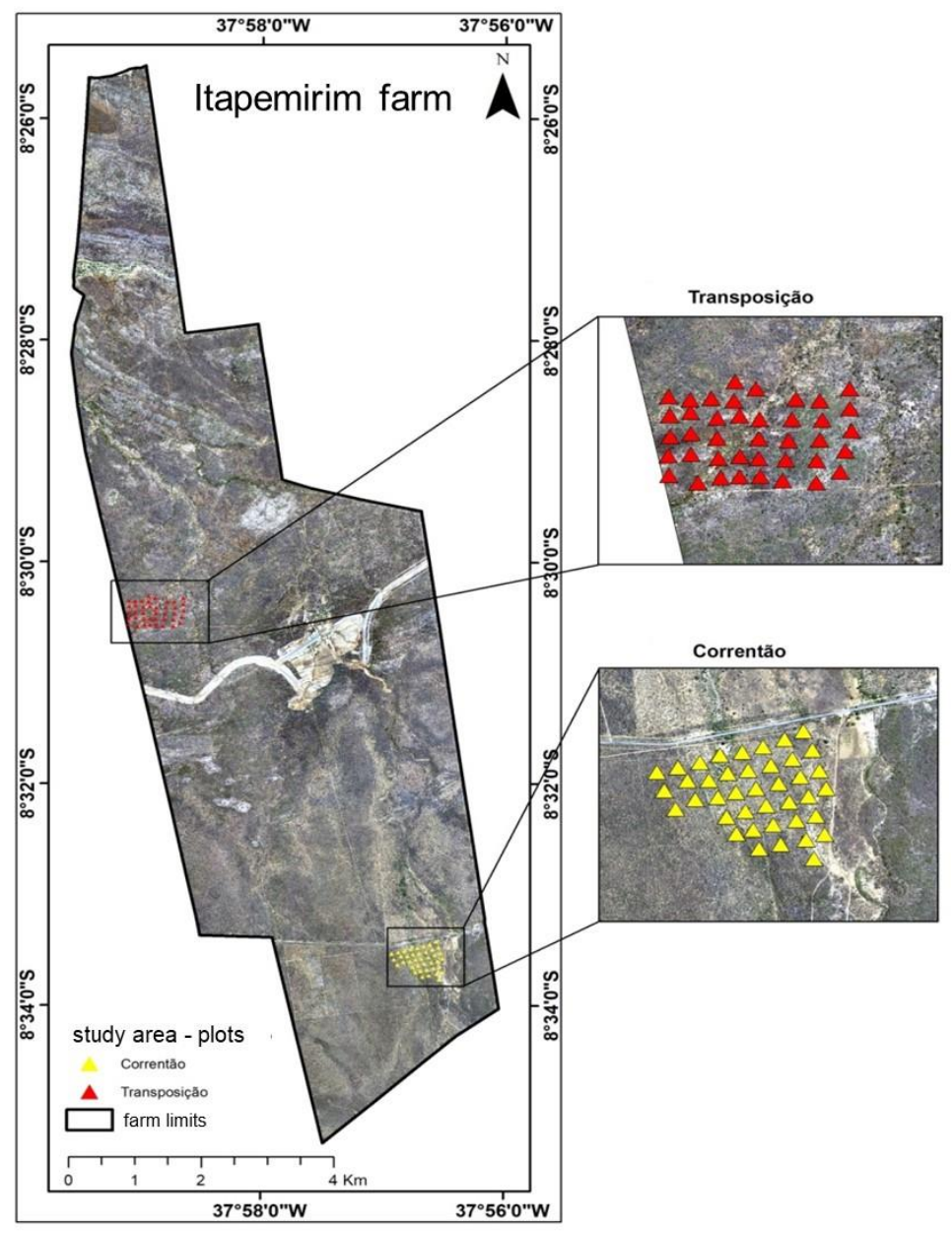

336 Fig. 2 Sampling procedure used in the two inventoried areas in the Municipality of

\section{Floresta, Pernambuco}

The vegetation in these areas is predominantly Caatinga (dry tropical forest), meaning savanna-steppe characterized by shrub-tree vegetation along with the presence 341 of cacti and herbaceous strata (IBGE, 2012). The climate is BSh according to the 
342 Köppen classification, a hot semi-arid region with an average annual precipitation of approximately 400 to $500 \mathrm{~mm}$, with a rainy period from January to April, and an average annual temperature of $26.1^{\circ} \mathrm{C}$. Its distribution in temperature and precipitation throughout the year studied (2014) in the municipalities belonging to the study area are shown in Figure 3. The municipality has an area of $3,643.97 \mathrm{Km}^{2}$ and an average altitude of $323 \mathrm{~m}$ (EMBRAPA, 2007).

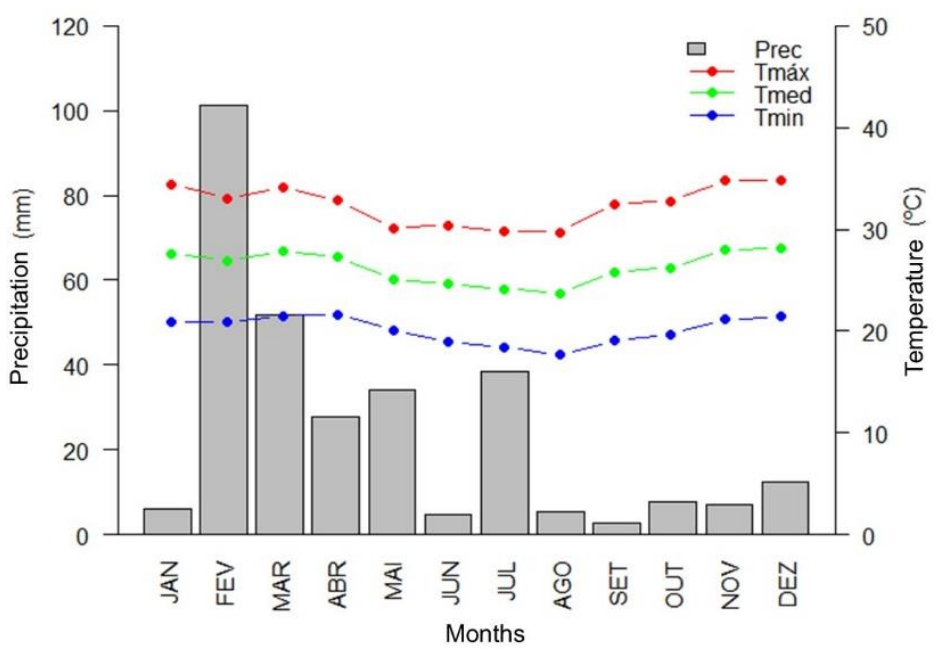

Fig. 3 Distribution of air temperature and precipitation over the year 2014 in the study area by the nearest weather station. Source: Agritempo adjusted. Source: Agritempo, 2018 (adjusted).

\section{Estimation of the biomass/carbon stock in the field}

355 Plots, which had already been inventoried, were used to facilitate logistics and data collection in each area (Fig. 2). A total of 40 plots in each area have been monitored since 2008. They are systematically distributed and each has 20 x $20 \mathrm{~m}\left(400 \mathrm{~m}^{2}\right)$. They are $80 \mathrm{~m}$ apart, $50 \mathrm{~m}$ from the edge. All arboreous individuals with circumference measured at $1.30 \mathrm{~m}$ above the ground $(\mathrm{CAP}) \geq 6.0 \mathrm{~cm}$ were identified, labeled and measured, and the total heights $(\mathrm{Ht})$ were measured by a clinometer. 

previously developed local equation (Equation 1), with subsequent conversion to carbon

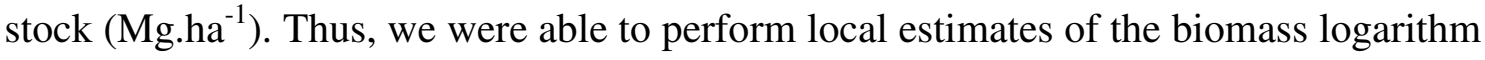
using DAP and Ht logarithms as independent variables, as shown in the equation below: TAGB $=\exp (-3.5336+1.9126 \times \ln (\mathrm{DAP})+1.2438 \times \ln (\mathrm{Ht}))$

Where: DBH is the diameter of the tree at breast height $(1.30 \mathrm{~m}) \mathrm{in} \mathrm{cm} ; \mathrm{Ht}$ is the height of the tree $(\mathrm{m})$. This equation was developed for the site and reported an Akaike Information Criterion (AIC) value of 573.77; an adjusted determination coefficient $\left(\mathrm{R}^{2} \mathrm{Adj}\right)$ of 0.90 ; absolute square errors (RMSE) of $18.28 \mathrm{~kg}^{\mathrm{t}} \mathrm{trees}^{-1}$ and bias of 0.20 kg.trees ${ }^{-1}$, respectively.

Next, the estimated biomass was converted using the average carbon fraction $(\mathrm{CF} \approx 48 \%$ ) of the caatinga woody species (Dalla-Lana et al. 2019) for carbon stock estimates $\left(\mathrm{Mg}_{\mathrm{g}} \mathrm{ha}^{-1}\right)$. In addition, it has traditionally been assumed that the carbon content of a tree's dry biomass is $50 \%$ for estimating carbon stocks for sites (Brown and Lugo, 1982; Roy et al. 2001; Malhi et al. 2004), but it should be emphasized that the carbon fraction of the wood may exhibit some small variations between species (Elias and Potvin, 2003). Thus, the carbon stock is assumed as follows:

382 Where: TAGC is the estimated total aboveground carbon stock $\left(\mathrm{Mg}^{-h a^{-1}}\right)$; TAGB is the total estimated aboveground biomass $\left(\mathrm{Mg} \cdot \mathrm{ha}^{-1}\right)$; $\mathrm{CF}$ is the carbon fraction (48\%). 
biomass and carbon predictions were for 2014 and are summarized in Table 1 . The

choice of this measurement period was defined according to the same LiDAR flyover year in the areas.

Table1. Descriptive values (mean and standard deviation) and number of individuals

and total shafts sampled in the permanent plots of the study areas (2014).

392

\begin{tabular}{|c|c|c|c|c|c|c|c|c|c|c|c|}
\hline \multirow{2}{*}{ Areas } & \multicolumn{2}{|c|}{ DBH $(\mathrm{cm})$} & \multicolumn{2}{|c|}{$\mathrm{Ht}(\mathrm{m})$} & \multicolumn{2}{|c|}{$\operatorname{AGB}\left(\mathrm{Mg} \cdot \mathrm{ha}^{-1}\right)$} & \multicolumn{2}{|c|}{$\operatorname{AGC}\left(\mathrm{Mg} \cdot \mathrm{ha}^{-1}\right)$} & \multirow{2}{*}{$\mathrm{N}^{\circ}$ Plots } & \multirow{2}{*}{$N^{\circ}$ Ind. } & \multirow{2}{*}{$\mathrm{N}^{\circ}$ stem } \\
\hline & $\bar{x}$ & $\sigma$ & $\bar{x}$ & $\sigma$ & $\bar{x}$ & $\sigma$ & $\bar{x}$ & $\sigma$ & & & \\
\hline Transposição & 3,85 & 2,37 & 3,97 & 0,95 & 9,327 & 5,442 & 4,66 & 27 & 40 & 1728 & 4576 \\
\hline Correntão & 11,44 & 5,4 & 3,64 & 0,92 & 24,94 & 24,95 & 12,47 & 12,47 & 40 & 996 & 2903 \\
\hline
\end{tabular}

Estimation of the biomass/carbon stock by LiDAR data

The LiDAR data used in this study were made available by the Pernambuco Three-

Dimensional Program (PE3D) inserted in the Pernambuco Water Sustainability Program

(PSHPE) with the objective of mapping the entire territory of the State of Pernambuco using its services covering aerophotogrammetric and laser profiling. They were collected in August 2014 using a Leica ALS50 system coupled to a BEM-810 C -

Seneca II - Prefix PT-RQA aircraft, with it being possible to view their characteristics 400 below (Table 2).

401

402

Table 2. Details of acquisition of LiDAR data.

\begin{tabular}{cc}
\hline Atributo & Valores \\
\hline Lidar System & ALS-50 LEICA \\
Flight altitude $(\mathrm{m})$ & 3.068 \\
Data de aquisição & $10 / 08 / 2014$ \\
opening angle $\left({ }^{\circ}\right)$ & 34,5 \\
Scanner frequency $(\mathrm{Kz} ; \mathrm{Hz})$ & $36,8 \mathrm{~Hz}$ \\
Pulse density $\left(\right.$ pulses $\left.\cdot \mathrm{m}^{2}\right)$ & 0,5 \\
Datum & Sirgas 2000 \\
\hline
\end{tabular}


405 Tridimensional Program website (http://www.pe3d.pe.gov.br/mapa.php), it was

406

407 necessary to change the format from ".xyzi" to ".las "using the LAS Utility software. Thus, a descriptive report with several important characteristics of the LiDAR data set was produced with the Fusion3.8 software program using the "Catalog" tool.

Therefore, the returns which were on the soil surface (points on the soil surface) were filtered from the LiDAR point cloud using the "Ground Filter" tool. The next step for both areas was to obtain the Digital Terrain Model (DTM) using the "Grid Surface Create" tool and the Digital Surface Model (DSM) using the "canopy model” tool.

It was first necessary to normalize the data in order to carry out the subsequent analyzes with the metrics of only the trees. This task was performed by subtracting the DSM data from the DTM data using the "clipdata" tool. The next step was to obtain the Canopy Height Digital Model (CHM) with the aid of the "canopymodel" tool to obtain the metric value for each plot of the two areas, in which it was necessary to perform the clipping by plot using the shape file of the plots with the point cloud using the "Polyclip DATA" tool.

The LiDAR metrics calculate a series of estimates of descriptive statistical parameters of the LiDAR point cloud and in this study were generated from the "cloud metrics" tool. Thus, a total of 26 metrics were generated at the end of the data processing by the point clouds in each sample unit in the different areas. These metrics are the most used in biomass and carbon estimation studies, categorized according to their origin and calculated symbology (Table 3 ). 
427 Table 3. List of LiDAR metrics evaluated in the study, obtained from the cloudmetrics tool of the Fusion v. 3.8

\begin{tabular}{lll}
\hline Category & \multicolumn{1}{c}{ LiDAR metrics } & \multicolumn{1}{c}{ Symbology } \\
\hline & Maximum height & Elev.maximum \\
Minimum height & Elev.minimum \\
Mean height & Elev.mean \\
Modal height & Elev.mode \\
Standard deviation of heights & Elev.stddev \\
Height variation coefficient & Elev.CV \\
Height asymmetry & Elev.skewness \\
Kurtosis of height & Elev.kurtosis \\
Median of absolute deviations from the general & Elev.MAD.median \\
mean & Elev.P01 \\
01th Percentile of height & Elev.P05 \\
05th percentile of height & Elev.P10 \\
10th percentile of height & Elev.P20 \\
20th percentile of height & Elev.P25 \\
25th percentile of height & Elev.P30 \\
30th percentile of height & Elev.P40 \\
40th percentile of height & Elev.P50 \\
50th percentile of height & Elev.P60 \\
60th percentile of height & Elev.P70 \\
70th percentile of height & Elev.P75 \\
75th percentile of height & Elev.P80 \\
80th percentile of height & Elev.P90 \\
90th percentile of height & Elev.P95 \\
95th percentile of height & Elev.P99 \\
99th percentile of Height & Canopy.relief.ratio \\
Canopy Relief Ratio & Percentage.all.returns.above.1.30 \\
Percentage of all returns above 1.30 & \\
Canopy & & \\
density & & \\
Cang & & \\
& &
\end{tabular}
${ }^{1}$ Canopyreliefratio ((HMEAN 2 HMIN)/(HMAX 2 HMIN));

Some of the main metrics used in predicting biomass and carbon are described below:

433 Elev.maximum = Maximum height: this is the highest value found in the measurement range in meters within each sample unit, considering variations at each meter along the walking axis.

436 Elev.mean = Mean height: this is the mean value of the highest points, considering 437 variations every meter in the measurement range in meters within each sample unit 438 (Equation 3). 
$439 \quad$ Elev.mean $=\frac{1}{n} \times \sum_{i=1}^{n} h_{i}$

$440 \quad(3)$

441 Elev.stddev $=$ Standard deviation of height in the LiDAR point cloud:

$442 \quad$ Elev.stddev $=\sqrt{\frac{1}{n-1} \times \sum_{i=1}^{n}\left(h_{i}-h_{m e d}\right)^{2}}$

443

(4)

444 Where: hmean = mean height of the point cloud.

445 Elev.CV $=$ Height variation coefficient in the LiDAR point cloud:

$446 \quad h_{c v}=\frac{h_{\text {desv }}}{h_{m e d}}$

$447 \quad(5)$

448 Height percentiles in the LiDAR point cloud (hpi): The $\mathrm{i}^{\text {th }}$ percentile of $\mathrm{n}$ points 449 traditionally represented in the LiDAR point cloud, ordered in height values 450 corresponds to the value which occupies the $\mathrm{K}$ position of the data set, as in the 451 following equation:

$452 \quad K=\frac{h_{p i}(n+1)}{100}$

$453 \quad(6)$

454 Where: $\mathrm{K}=$ value that occupies the $\mathrm{i}^{\text {th }}$ percentile in height in the point cloud; $\mathrm{h}$ pi $=\mathrm{i}_{-}{ }^{\text {th }}$ 455 percentile in height in the point cloud.

456

457

Modeling the biomass/carbon stock using LiDAR data

458

The "R Project for Statistical Computing” Lidar Data_Analysis Tools (R Development

459

Core Team, 2017) and ArcGIS $10^{\circledR}$ software programs were used to construct, validate and apply predictive models and generate representative biomass and forest carbon maps in the different areas. 
Forest Service - Remote Sensing Applications Center, written in Python language, and works as an interface of R. The Lidar Data_Analysis Tools was designed to streamline the statistical regression analysis process involving LiDAR metrics generated by the North American Forest Service, and in fact works as a graphical interface to access the statistical modeling packages available in $\mathrm{R}$ which simplify processing large volumes of data (Silva et al., 2017a).

Next, three data analysis approaches were used to construct the biomass allometric models per hectare according to the LiDAR metrics for the two areas: Multiple linear regression, Multiple linear regression with Stepwise and Multiple linear regression with Principal Components - PCA.

First, traditional modeling was used employing multiple linear regression. Thus, it is assumed that there is a linear relationship between a Y variable (biomass; carbon) and $\mathrm{k}$ independent variables, $\mathrm{xj}(\mathrm{j}=, \ldots, \mathrm{k}=\mathrm{LiDAR}$ point cloud metrics). The mathematical model which expresses the equation of multiple linear regression has the

477 following form: $Y=\beta_{0}+\beta_{1} X_{1}+\beta_{2} X_{2}+\cdots+\beta_{k} X_{k}+\varepsilon$

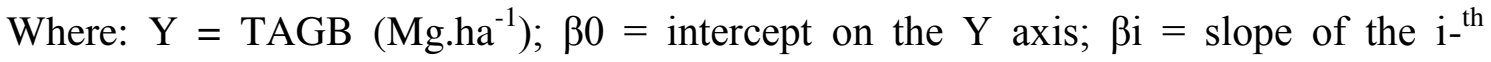
explanatory variable; $\mathrm{k}=$ number of explanatory variables; $\mathrm{e}=$ random error.

Regression analysis was used with an emphasis on solving most of the forest problems, especially when it is intended to obtain estimates of forest parameters through biometric relationships. A careful analysis was performed in selecting the best metrics from the LiDAR point cloud candidates for modeling among the metrics generated by 
487 the LiDAR data processing for construction the models. According to (Silva et al. 488 2017a), Pearson's linear correlation test $\left(\mathrm{r}^{2}\right)$ should first be applied for this selection to 489 obtain the correlation between the predictive variables and to evaluate the possible existence of collinearity between them. Variables with $\mathrm{R}^{2}>0.9$ will be excluded from the analysis to avoid the presence of collinearity.

Second, the Stepwise technique was applied using the regsubsets function of the "leaps" package in $\mathrm{R}$ to obtain subsets of independent variables which are candidates for composing the definitive biomass and carbon models in the different areas. This method performs an exhaustive search to select the best combinations of independent variables by minimizing Akaike's information criterion (AIC), and rearranging them into subsets which may later give rise to the selected models. Regsubsets require the use of a maximum number (represented by the nvmax argument) of independent variables for the growing construction of these subsets.

Third, the principal component technique (PCA) was applied to the selected LiDAR metrics, and the metrics most likely to contribute to developing the model were identified by inspecting the eigenvectors on each principal component. Then, the metrics with the highest load on the PCs were used as input variables in multivariate linear regression models that predicted biomass per hectare.

An example of using PCA including the equations used to obtain the eigenvalues, eigenvectors and principal components (PC) can be found in Jensen 507 (2005). PCA was applied in the present study to the selected LiDAR metrics using the 508 prcomp function of the statistics package in $\mathrm{R}$ ( $\mathrm{R}$ Core Team, 2017). A correlation matrix derived from the LiDAR metrics provided the basis for calculating eigenvalues and eigenvectors and for the subsequent determination of PC scores. Each score represented a transformed metric from the linear combination of LiDAR metrics. 
512 Differences in the contribution of each LiDAR metric to the variability in the data set,

513 as well as the similarity in the calculated metrics (Silva et al., 2017a) can be established

514 by analyzing the eigenvectors and the PC score.

515

\section{Evaluation of models}

517 The model parameters were estimated using the Ordinary Least Squares (OLS -

518 Ordinary Least Squares) method in all the modeling methods described. The parameters

519 were generally calculated using all plots sampled in each area and will be assumed to be

520 the true parameters that represent the biomass and carbon stock at each location.

521 For each of the criteria established for the biomass estimation, the obtained

522 equations were analyzed using comparisons of statistical criteria obtained according to

523 the following equations:

$524 \quad \mathrm{R}_{\mathrm{aj}}^{2}=\mathrm{R}^{2}-\left[\frac{\mathrm{k}-1}{\mathrm{n}-\mathrm{k}}\right] \times\left(1-\mathrm{R}^{2}\right)$

$525 \quad(8)$

$526 \quad \mathrm{RMSE}=\sqrt{\frac{\sum_{\mathrm{i}=1}^{\mathrm{n}}\left(\mathrm{Y}_{\mathrm{i}}-\widehat{\mathrm{Y}}_{\mathrm{i}}\right)^{2}}{\mathrm{n}}}$

$527(9)$

528 In which: $Y i$ is the replied variable (biomass and/or carbon) observed in the field (i);

$529 \widehat{Y}_{l}$ is the estimate (biomass and/or carbon), $\mathrm{k}$ is the number of parameters and $n$ is the 530 total number of observations.

531

532 Generation of stock maps using LiDAR data

533 After selecting the best model, the AsciiGrid Input function, available in the yaInpute in

534 R package (Crookston and Finley, 2007), was used to view the estimates generated by 535 the model on a map. The map expresses a grid where each cell represents a $5 \times 5 \mathrm{~m}$ grid 
537 adopted methodology can be seen in the organization chart below (Fig. 4).

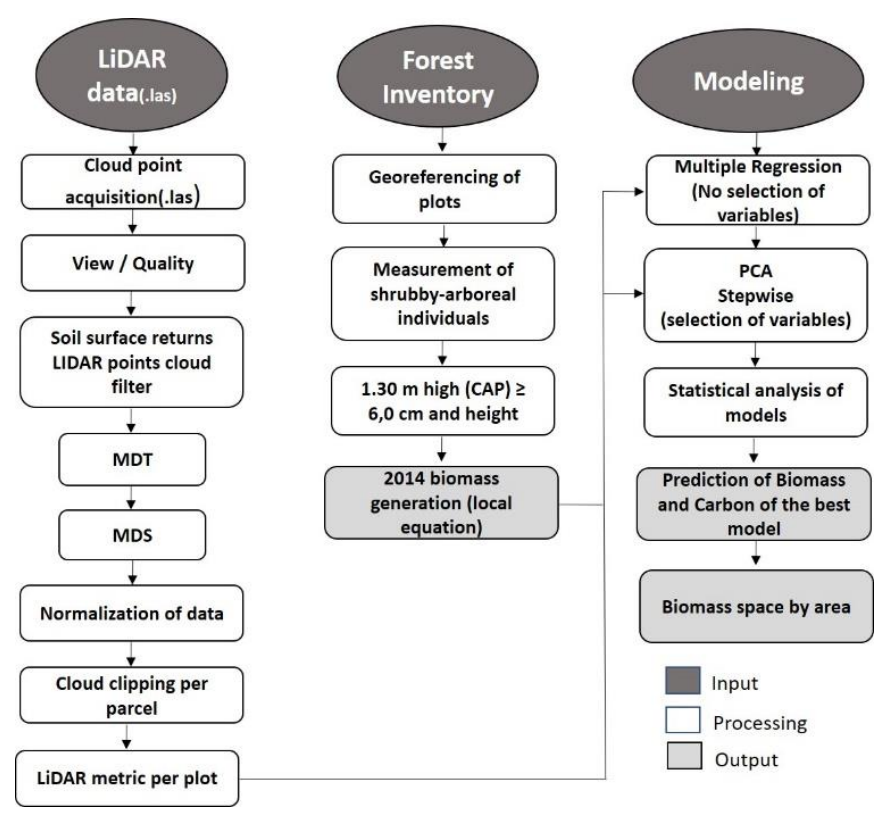

539 Fig. 4 Flowchart of the methodology adopted and the resulting products.

\section{List of abbreviations}

541 IBGE - Instituto Brasileiro de Geografia e Estatística

542 EMBRAPA - Empresa Brasileira de Pesquisa Agropecuária

543 TAGB - Total aboveground biomass

544 TAGC - Total aboveground carbon

\section{Availability of data and materials}

547 The data are available upon a reasonable request to the Authors.

\section{Ethics approval and consent to participate}

549 Not applicable.

\section{Consent for publication}

551 Not applicable.

\section{Competing interests}

553 The authors declare no conflict of interest 


\section{Funding}

555

Not applicable.

556

557

\section{Authors' contributions}

558

Cinthia Oliveira and Rinaldo Ferreira planned the study and wrote the manuscript,

559 Cinthia Oliveira, Robson Lima and José Aleixo da Silva participated in the processing 560 data LiDAR, calculation and modeling of the data and wrote the manuscript. Emanuel 561 Silva, Josias Divino Lucena, Anderson da Silva, Nattan Adler dos Santos, Cybelle 562 Souto Maior, Mayara Pessoa, Iran Jorge collected and processed the data inventory. 563 They also commented on the manuscript. The authors read and approved the final 564 manuscript.

Acknowledgements

567 The authors are grateful for the help of the researchers Rinaldo Caraciolo Ferreira, José 568 Aleixo da Silva and Robson Lima who collaborated to complete this work. We also 569 thank the forestry worker and German Cespedez, who is responsible for the data access to the area for developing this work. The authors are grateful for the financial support granted by the National Council for Scientific and Technological Development (CNPq) by the productivity bag of the second and third co-authors, project leaders.

573

\section{Authors' Information}

Cinthia Pereira de Oliveira - https://orcid.org/0000-0001-5158-7866

576 Rinaldo Luiz Caraciolo Ferreira - https://orcid.org/0000-0001-7349-6041

577 José Antônio Aleixo da Silva - https://orcid.org/0000-0003-0675-3524 
581 Achard F, House JI. 2015. Reporting carbon losses from tropical deforestation with Pan-tropical biomass maps. Environ Res Lett. 10(10):101002.

583 Althoff TD, Menezes RSC, Pinto A de S, Pareyn FGC, Carvalho AL de, Martins JCR, 584 de Carvalho EX, Silva ASA da, Dutra ED, Sampaio EV de SB. 2018. Adaptation of the 585 century model to simulate $\mathrm{C}$ and $\mathrm{N}$ dynamics of Caatinga dry forest before and after 586

Anderson KE, Glenn NF, Spaete LP, Shinneman DJ, Pilliod DS, Arkle RS, McIlroy SK, Derryberry DR. 2018. Estimating vegetation biomass and cover across large plots in shrub and grass dominated drylands using terrestrial lidar and machine learning. Ecol Indic. 84:793-802.

Avitabile V, Herold M, Henry M, Schmullius C. 2011. Mapping biomass with remote sensing: a comparison of methods for the case study of Uganda. Carbon Balance Manag $\begin{array}{llllll}\text { [Internet]. } & \text { [accessed } & 2018 & \text { Sep } & 27] & 6(1) \text {. }\end{array}$ https://cbmjournal.biomedcentral.com/articles/10.1186/1750-0680-6-7

Becknell JM, Keller M, Piotto D, Longo M, Nara dos-Santos M, Scaranello MA, Bruno de Oliveira Cavalcante R, Porder S. 2018. Landscape-scale lidar analysis of aboveground biomass distribution in secondary Brazilian Atlantic Forest. Biotropica. 50(3):520-530.

Brahma B, Nath AJ, Sileshi GW, Das AK. 2018. Estimating biomass stocks and potential loss of biomass carbon through clear-felling of rubber plantations. Biomass Bioenergy. 115:88-96.

Brown S, Lugo AE. 1982. The storage and production of organicmatter in tropical forests and their role in the global carboncycle. Biotropica. 14:161-187

Chave J, Andalo C, Brown S, Cairns MA, Chambers JQ, Eamus D, Fölster H, Fromard F, Higuchi N, Kira T, et al. 2005. Tree allometry and improved estimation of carbon stocks and balance in tropical forests. Oecologia. 145(1):87-99.

Chave J, Réjou-Méchain M, Búrquez A, Chidumayo E, Colgan MS, Delitti WBC, Duque A, Eid T, Fearnside PM, Goodman RC, et al. 2014. Improved allometric models to estimate the aboveground biomass of tropical trees. Glob Change Biol. 20(10):31773190 .

Chen Q, Lu D, Keller M, dos-Santos M, Bolfe E, Feng Y, Wang C. 2015. Modeling and Mapping Agroforestry Aboveground Biomass in the Brazilian Amazon Using Airborne Lidar Data. Remote Sens. 8(1):21.

Coomes DA, Dalponte M, Jucker T, Asner GP, Banin LF, Burslem DFRP, Lewis SL, Nilus R, Phillips OL, Phua M-H, Qie L. 2017. Area-based vs tree-centric approaches to mapping forest carbon in Southeast Asian forests from airborne laser scanning data. 
619 Crookston NL, Finley A. 2008. Yaimpute: An R package for k-NN imputation. Journal 620 of Statistical Software. 23(10): 1-16. https://doi.org/10.18637/jss.v023.i10.

621 Crowther TW, Glick HB, Covey KR, Bettigole C, Maynard DS, Thomas SM, Smith JR, 622 Hintler G, Duguid MC, Amatulli G, et al. 2015. Mapping tree density at a global scale. 623 Nature. 525(7568):201-205.

624 Dalla Lana M. et al. 2018. Biomass equations for caatinga species. Nativa 6:517-525. http://dx.doi.org/10.31413/nativa.v6i5.5361

Duncanson L, Huang W, Johnson K, Swatantran A, McRoberts RE, Dubayah R. 2017. Implications of allometric model selection for county-level biomass mapping. Carbon Balance Manag [Internet]. [accessed 2018 Aug 16] 12(1). https://cbmjournal.biomedcentral.com/articles/10.1186/s13021-017-0086-9

630 Elias M, Potvin C. 2003. Assessing inter- and intra-specific variation in trunk carbon 631 concentration for 32 neotropical tree species. Canadian Journal of Forest Research. 33(6): 1039-1045. https://doi.org/10.1139/x03-018.

Empresa Brasileira de Pesquisa Agropecuária- EMBRAPA. Zoneamento Agroecológico do Estado de Pernambuco - ZAPE. 2007. Disponível em: http://www.uep.cnps.embrapa.br/zape. Acesso em: 15 abr. 2017.

Figueiredo EO, d'Oliveira MVN, Braz EM, de Almeida Papa D, Fearnside PM. 2016.

LIDAR-based estimation of bole biomass for precision management of an Amazonian forest: Comparisons of ground-based and remotely sensed estimates. Remote Sens Environ [Internet]. [accessed 2018 Nov 12] 187:281-293. https://linkinghub.elsevier.com/retrieve/pii/S0034425716303984

641 Hernández-Stefanoni JL, Johnson KD, Cook BD, Dupuy JM, Birdsey R, Peduzzi A, 642 Tun-Dzul F. 2015. Estimating species richness and biomass of tropical dry forests using 643 LIDAR during leaf-on and leaf-off canopy conditions.Goslee S, editor. Appl Veg Sci. 644 18(4):724-732.

645 Instituto Brasileiro de Geografia e Estatística, Coordenação de Recursos Naturais e 646 Estudos Ambientais. 2012. Manual técnico da vegetação brasileira.

647 Jensen JR. 2005. Introductory digital image processing: a remote sensing perspective. 648 Upper Saddle River, N.J: Prentice Hall.

Kachamba D, Ørka H, Næsset E, Eid T, Gobakken T. 2017. Influence of Plot Size on Efficiency of Biomass Estimates in Inventories of Dry Tropical Forests Assisted by Photogrammetric Data from an Unmanned Aircraft System. Remote Sens. 9(6):610. based estimates of tropical forest structure in complex terrain: opportunities and tradeoffs for REDD+. Carbon Balance Manag [Internet]. [accessed 2018 Nov 12] 10(1). 
659 Magnusson M. et al. 2007. Effects on Estimation Accuracy of Forest Variables Using 660 Different Pulse Density of Laser Data. Forest Science. 53(6): 619-626. Disponível em: 661 https://pub.epsilon.slu.se/3651/. Acesso em: 22 jun. 2018.

Malhi, Y. et al. 2004. The above-ground coarse wood productivity of 104 Neotropical forest plots. Global Change Biology. 10(5): 563-591. https://doi.org/10.1111/j.15298817.2003.00778.x.

665

666

667

668

669

670

671

672

673

674

675

676

677

Martinuzzi S, Gould WA, Vierling LA, Hudak AT, Nelson RF, Evans JS. 2013. Quantifying Tropical Dry Forest Type and Succession: Substantial Improvement with LiDAR. Biotropica. 45(2):135-146.

Mohebalian PM, Aguilar FX. 2018. Beneath the Canopy: Tropical Forests Enrolled in Conservation Payments Reveal Evidence of Less Degradation. Ecol Econ. 143:64-73.

Naveenkumar J, Arunkumar KS, Sundarapandian Sm. 2017. Biomass and carbon stocks of a tropical dry forest of the Javadi Hills, Eastern Ghats, India. Carbon Manag. 8(56):351-361.

Nelson R, Margolis H, Montesano P, Sun G, Cook B, Corp L, Andersen H-E, deJong B, Pellat FP, Fickel T, et al. 2017. Lidar-based estimates of aboveground biomass in the continental US and Mexico using ground, airborne, and satellite observations. Remote Sens Environ [Internet]. [accessed 2018 Nov 12] 188:127-140. https://linkinghub.elsevier.com/retrieve/pii/S0034425716304175

R Core Team. 2017. R: A language and environment for statistical computing. $\mathrm{R}$ Foundation for Statistical Computing, Vienna, Austria. URL https://www.Rproject.org/.

Roy J. 2001.Terrestrial global productivity. San Diego: Academic.

Saatchi S, Malhi Y, Zutta B, Buermann W, Anderson LO, Araujo AM, Phillips OL, Peacock J, ter Steege H, Lopez Gonzalez G, et al. 2009. Mapping landscape scale variations of forest structure, biomass, and productivity in Amazonia. Biogeosciences Discuss. 6(3):5461-5505.

Sampaio EV, Silva GC. 2005. Biomass equations for Brazilian semiarid caatinga plants. Acta Bot Bras. 19(4):935-943.

Silva C, Hudak A, Vierling L, Klauberg C, Garcia M, Ferraz A, Keller M, Eitel J, Saatchi S. 2017a. Impacts of Airborne Lidar Pulse Density on Estimating Biomass Stocks and Changes in a Selectively Logged Tropical Forest. Remote Sens. 9(10):1068.

Silva C, Hudak A, Vierling L, Klauberg C, Garcia M, Ferraz A, Keller M, Eitel J, Saatchi S. 2017b. Impacts of Airborne Lidar Pulse Density on Estimating Biomass Stocks and Changes in a Selectively Logged Tropical Forest. Remote Sens [Internet]. [accessed 2018 Nov 12] 9(10):1068. http://www.mdpi.com/2072-4292/9/10/1068 
Silva CA, Klauberg C, Hudak AT. 2014. Mapeamento de estoques de carbono acima do solo utilizando dados LiDAR em plantações de Eucalyptus spp no estado de São Paulo, Brasil. Sci For. 42(104):14.

Silva CA, Klauberg C, Hudak AT, Vierling LA, Liesenberg V, Carvalho SPC e, Rodriguez LCE. 2016. A principal component approach for predicting the stem volume in Eucalyptus plantations in Brazil using airborne LiDAR data. Forestry. 89(4):422433.

Somogyi Z, Cienciala E, Mäkipää R, Muukkonen P, Lehtonen A, Weiss P. 2007. Indirect methods of large-scale forest biomass estimation. Eur J For Res. 126(2):197207.

Takahashi T, Awaya Y, Hirata Y, Furuya N, Sakai T, Sakai A. 2010. Stand volume estimation by combining low laser-sampling density LiDAR data with QuickBird panchromatic imagery in closed-canopy Japanese cedar ( Cryptomeria japonica ) plantations. Int J Remote Sens [Internet]. [accessed 2018 Nov 12] 31(5):1281-1301. https://www.tandfonline.com/doi/full/10.1080/01431160903380623

Thomas V, Treitz P, McCaughey JH, Morrison I. 2006. Mapping stand-level forest biophysical variables for a mixedwood boreal forest using lidar: an examination of scanning density. Can J For Res [Internet]. [accessed 2018 Nov 12] 36(1):34-47. http://www.nrcresearchpress.com/doi/10.1139/x05-230 
Figures

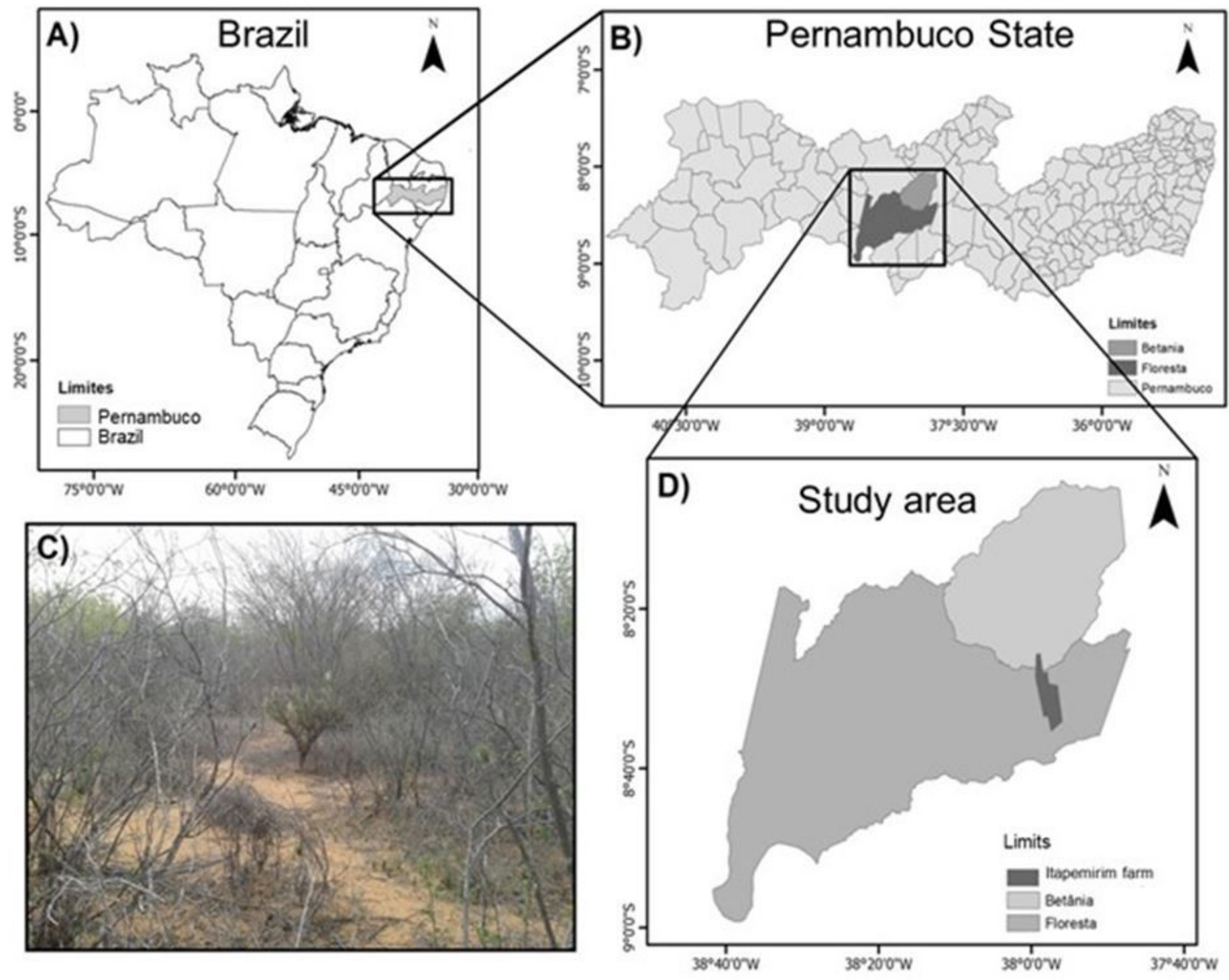

Figure 1

Coverage of the study area: A, B and D, and profile photo in Floresta C, in the hinterland of Pernambuco, Brazil. 


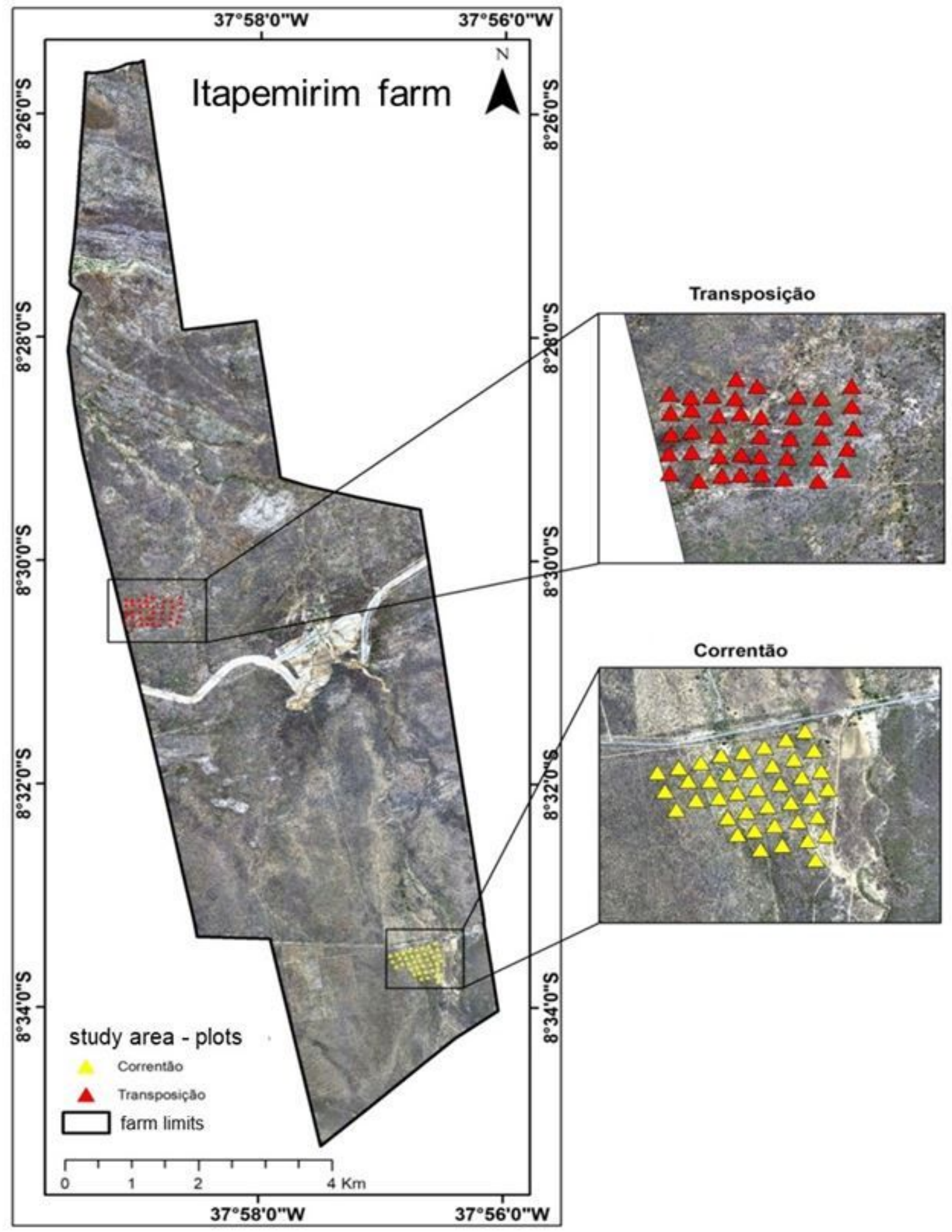

Figure 2

Sampling procedure used in the two inventoried areas in the Municipality of Floresta, Pernambuco. 


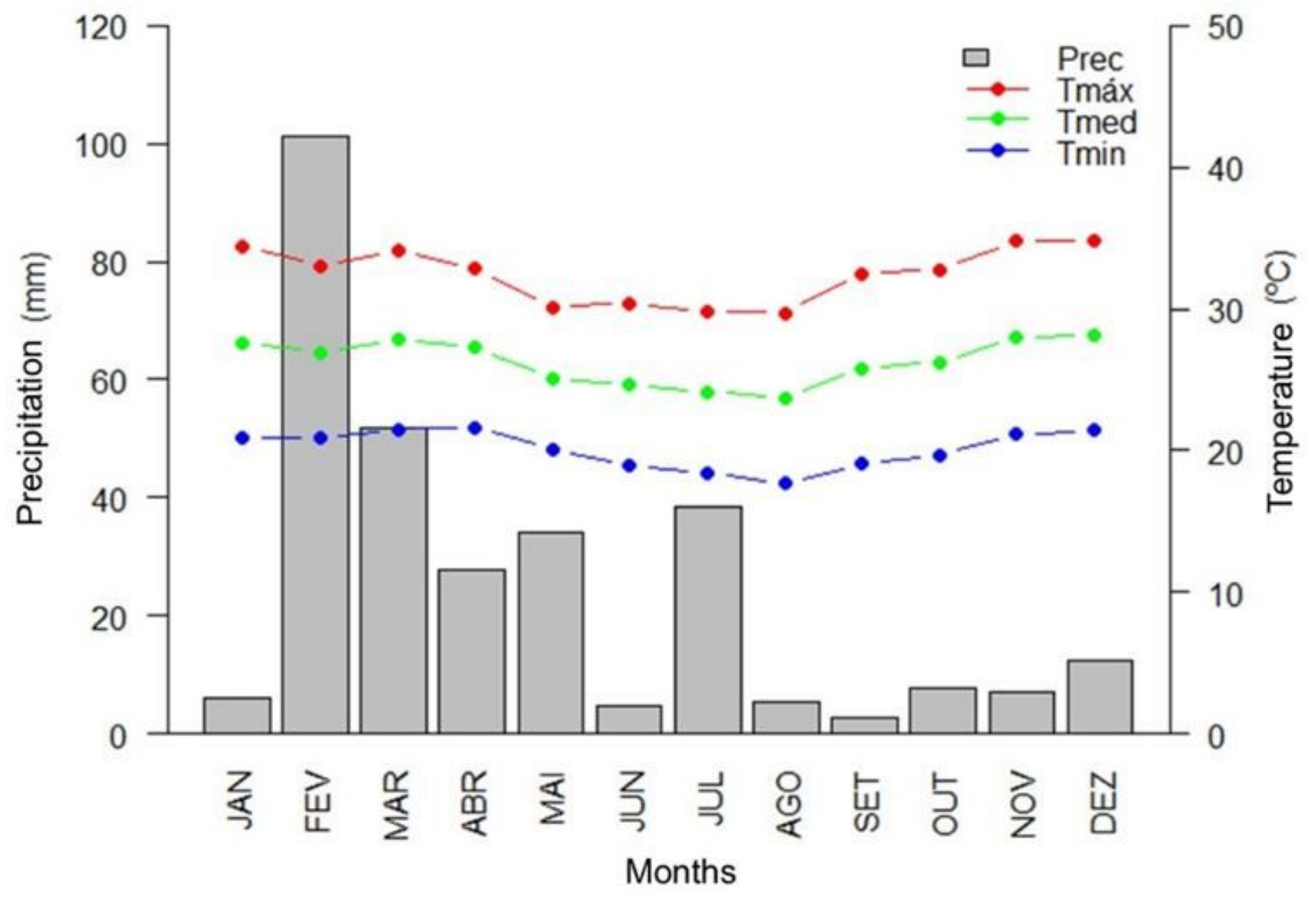

Figure 3

Distribution of air temperature and precipitation over the year 2014 in the study area by the nearest weather station. Source: Agritempo adjusted. Source: Agritempo, 2018 (adjusted). 


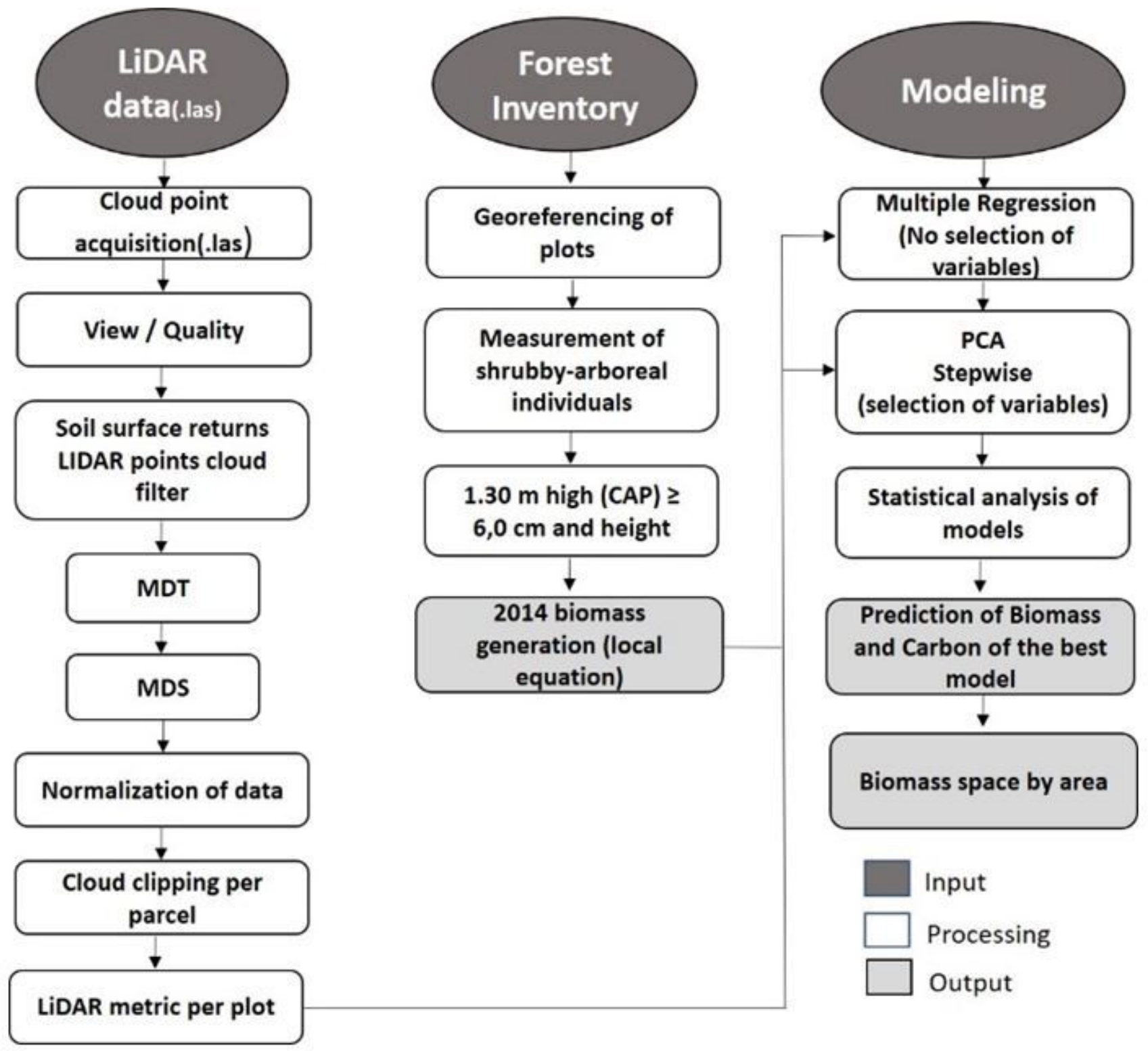

Figure 4

Flowchart of the methodology adopted and the resulting products. 

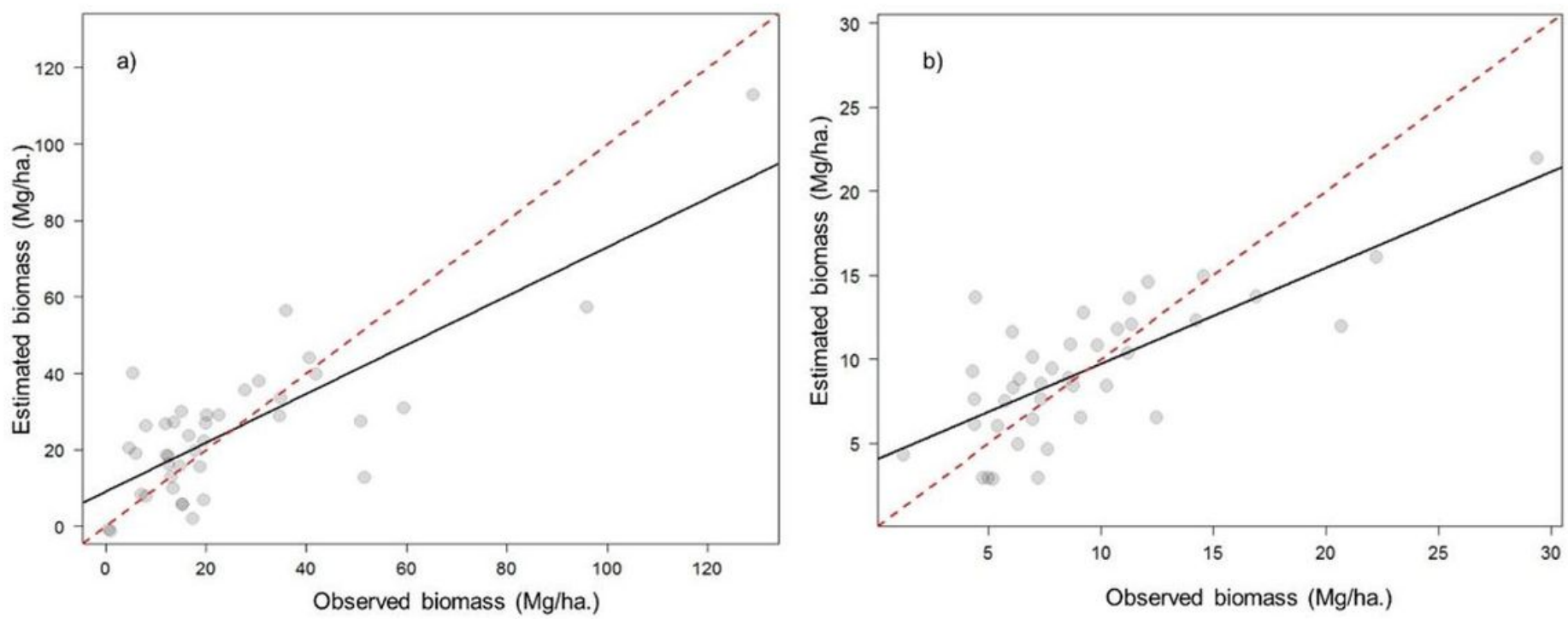

Figure 5

Predictions of the best allometric equations for the Correntão area (a) and Transposição (b) using the LiDAR metrics selected step by step in relation to the observed values. The solid black line indicates the fit of the equation and the red dotted line indicates the ideal fit in a 1: 1 ratio. 

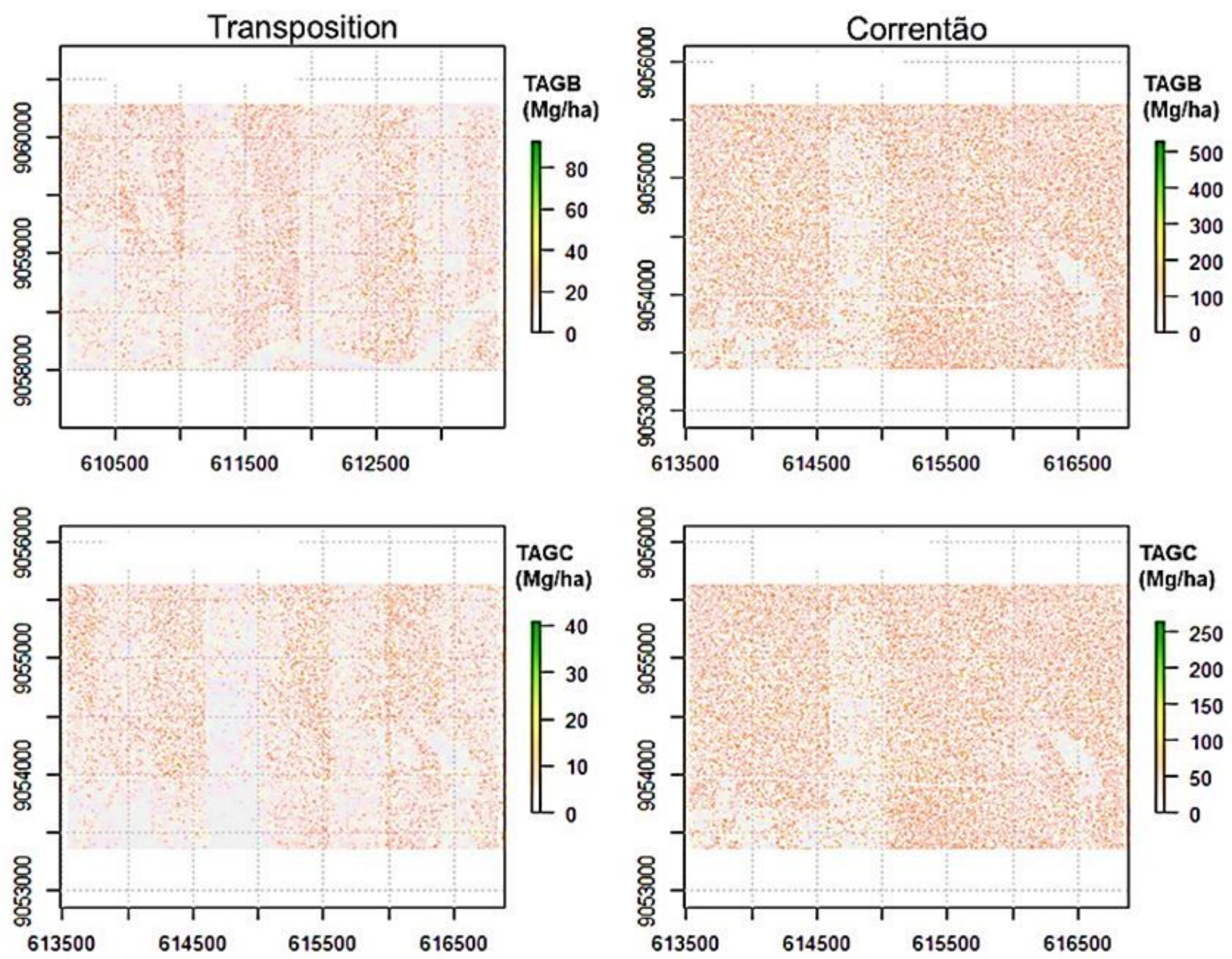

Figure 6

Spatialization of biomass and carbon based on Stepwise regression models defined according to the LiDAR metrics for the Transposição and Correntão areas. 